Jurnal Ilmu-Ilmu Peternakan 26 (2): 60 - 66

ISSN : 0852-3681

E-ISSN : 2443-0765

CFakultas Peternakan UB, http://jiip.ub.ac.id/

\title{
Pengaruh kualitas ransum berbeda terhadap bobot relatif kuning telur dan profil leukosit Ayam Kedu pasca tetas
}

\author{
Dwi Rahayu Apriasih, Nyoman Suthama, Hanny Indrat Wahyuni \\ Fakultas Peternakan dan Pertanian Universitas Diponegoro \\ Kompl. Drh. R. Soejono Koesoemowardojo-Tembalang, Semarang Kode pos 50275 \\ dwirahayuapriasih@gmail.com
}

\begin{abstract}
The research aimed to evaluate the effect of different quality of diet on yolk relative weight and leukocytes profile of post-hatch Kedu chicks. The research used 105 birds of day-old Kedu chicks, which were devided into T0 $=$ fasted for three days post-hatch continued feed farmer ration; T1 = farmer's ration; T2 = improved rations. Improved ration contains higher protein and energy than the farmer's ration. Completely randomized design (CRD) with split in time was assigned to the present study. The main plot was age of chicks and the subplot was dietary treatment. Parameters measured were yolk relative weight, leukocyte and differential leukocyte profiles. The results showed that there was no significant effect on either interaction ( $\mathrm{P}>0.05$ ) between age and dietary nutriens quality or the main plot on yolk relative weight, leukocytes and differential leukocyte profiles in Kedu chicks 6 days post-hatch. However, yolk relative weight was affected significantly by the sublot, and other parameters were the same. Conclusion of the research was that the yolk relative weight, leukocyte and differential leukocyte profiles remained stable in 6 days post-hatch Kedu chicks despite being given ration with the different nutrients quality, including fasted-group's chicks three days after hatch.
\end{abstract}

Keywords: post-hatch Kedu chicks, egg yolks, leukocyte profiles, improved ration.

\section{PENDAHULUAN}

Ayam Kedu merupakan jenis ayam kampung yang banyak ditemukan di kabupaten Temanggung. Produktivitas ayam Kedu relatif lebih tinggi dibandingkan ayam lokal lainnya dan lebih tahan terhadap penyakit serta kondisi lingkungan jika dibandingkan ayam non lokal. Namun, ayam Kedu hitam mengalami kendala dalam pengembangan populasinya karena memiliki pertumbuhan yang lambat. Hal ini disebabkan ketahanan tubuh ayam, terutama pada ayam pasca tetas yang masih rendah. Daya tahan tubuh ayam pasca tetas untuk tetap hidup dapat dipengaruhi oleh beberapa faktor antara lain faktor pemberian ransum dan kualitasnya, sehingga pemberian ransum untuk ayam pasca tetas perlu diperhatikan kandungan dan kecukupan gizinya (Pattison, 1993).

Pemeliharaan ayam pasca tetas perlu diperhatikan untuk meminimalkan terserang penyakit yang dapat menyebabkan kematian. Ayam pasca tetas mempunyai daya tahan tubuh yang masih lemah dan rentan terhadap penyakit. Disisi lain sumber makanan utama ayam pasca tetas adalah cadangan makanan yang tersimpan dalam tubuh yaitu berupa sisa kuning telur. Cadangan nutrisi dalam sisa kuning telur ini berguna untuk mempertahankan hidup ayam pasca tetas, sementara asupan nutrisi dari ransum 
belum maksimal. Parsons (1970) menyatakan bahwa menurunnya nafsu makan dan terganggunya penyerapan kuning telur dapat menurunkan kondisi tubuh anak ayam.

Penyerapan sisa kuning telur dalam tubuh ayam pasca tetas dapat dipengaruhi oleh ransum dan air minum yang diberikan. Gonzales et al., (2000) menyatakan bahwa sisa kuning telur dalam tubuh ayam akan lebih cepat digunakan pada anak ayam yang mendapatkan ransum lebih awal, dibandingkan pada anak ayam yang terlebih dahulu dipuasakan hingga 48 jam setelah menetas. Penyusutan kuning telur dalam tubuh ayam pasca tetas dipengaruhi oleh penundaan pemberian ransum saat pasca tetas dan kualitas nutrisi yang terkandung dalam ransum yang diberikan (Nataamijaya, 2008). Kuning telur dalam tubuh anak ayam pasca tetas berfungsi untuk mempertahankan daya tahan tubuh, karena mengandung protein tinggi yang digunakan untuk membantu pembentukan antibodi. Selain itu, kuning telur juga mengandung vitamin A dan E sebagai antioksidan dalam membantu daya tahan hidup anak ayam (Pattison, 1993).

Kandungan sisa kuning telur dalam tubuh anak ayam hampir sama dengan kandungan kuning telur dalam telur. Pattison (1993) menyatakan bahwa kandungan nutrisi dalam telur juga berfungsi untuk menjaga kondisi anak ayam setelah menetas karena kandungan nutrisi tersebut berperan sebagai cadangan makanan untuk beberapa hari setelah anak ayam menetas. Sisa kuning telur dalam tubuh anak ayam tersusun dari 50\% air, $28 \%$ protein, $20 \%$ lemak, dan $7 \%$ maternal antibodi (Widjaja, 1999). Hal ini mengindikasikan bahwa sisa kuning telur dalam tubuh anak ayam pasca tetas harus secepatnya diserap sehingga daya tahan tubuh anak ayam pasca tetas dapat dipertahankan atau bahkan menjadi lebih baik.

Daya tahan tubuh ayam dapat dilihat dari profil leukosit dan leukosit diferensial. Leukosit merupakan sel darah putih yang berfungsi untuk pertahanan tubuh dari suatu penyakit. Jumlah leukosit dapat dipengaruhi oleh beberapa faktor yaitu stres, aktifitas biologis, gizi, umur, jenis kelamin, hormon dan lingkungan (Arvah, 2015). Leukosit diferensial terdiri dari heterofil dan limfosit yang merupakan bagian dari sel darah putih yang juga berfungsi untuk pertahanan tubuh. Heterofil berfungsi sebagai pertahanan tubuh ayam terhadap pengaruh luar dan merupakan alat pendeteksi awal adanya infeksi (Mayes et al., 1997; Redmond et al., 2011). Limfosit berfungsi membentuk antigen yang digunakan untuk membentuk antibodi yang merupakan sistem kekebalan tubuh unggas (Yalcinkaya et al., 2008).

Berdasarkan latar belakang tersebut penelitian ini bertujuan untuk mengetahui pengaruh kualitas ransum berbeda terhadap bobot relatif kuning telur dan profil leukosit serta leukosit diferensial pada ayam Kedu pasca tetas. Penelitian ini diharapkan dapat memberikan manfaat bagi perkembangan dunia peternakan khususnya bagi para peternak ayam Kedu agar dapat mengetahui tentang kualitas ransum berbeda terhadap penyusutan kuning telur sehingga dapat meningkatkan daya tahan tubuh ayam Kedu pasca tetas.

\section{MATERI DAN METODE}

Penelitian menggunakan 105 ekor anak ayam Kedu hitam umur satu hari dengan menggunakan rancangan acak lengkap (RAL) pola Split in Time dengan 3 perlakuan dan 5 ulangan. Perlakuan ransum diterapkan selama 9 hari. Pemberian ransum berbeda diberikan dengan 3 perlakuan yaitu ayam dipuasakan setelah itu diberi ransum peternak, ayam diberi ransum peternak dan juga kelompok ayam yang diberi ransum perbaikan. Pemberian air minum secara ad libitum. Komposisi dan kandungan nutrisi ransum perlakuan disajikan pada Tabel 1. 
Tabel 1. Komposisi dan kandungan nutrisi ransum penelitian

\begin{tabular}{|c|c|c|}
\hline Bahan pakan & Ransum peternak & Ransum perbaikan \\
\hline & \multicolumn{2}{|c|}{-----------------------------\%--------------------------- } \\
\hline Jagung giling & 36,00 & 50,00 \\
\hline Dedak padi & 39,50 & 20,00 \\
\hline Bungkil kedelai & - & 21,00 \\
\hline Tepung ikan & - & 6,00 \\
\hline Konsentrat pedaging & 19,50 & - \\
\hline $\mathrm{CaCO}_{3}$ & - & 2,00 \\
\hline Premiks & 5,00 & 1,00 \\
\hline Total & 100,00 & 100,00 \\
\hline \multicolumn{3}{|l|}{ Kandungan nutrisi $^{1}$} \\
\hline Energi metabolis $(\mathrm{kkal} / \mathrm{kg})^{2}$ & $2.583,12$ & $2.887,20$ \\
\hline Protein kasar & 13,04 & 17,45 \\
\hline Lemak kasar & 2,31 & 2,30 \\
\hline Serat kasar & 8,22 & 4,59 \\
\hline Kalsium & 0,72 & 0,84 \\
\hline Posphor & 0,64 & 0,40 \\
\hline Metionin $^{3}$ & 0,26 & 0,36 \\
\hline $\operatorname{Lisin}^{3}$ & 0,76 & 1,04 \\
\hline Arginin $^{3}$ & 1,04 & 1,23 \\
\hline
\end{tabular}

${ }^{1}$ Hasil analisis proksimat di Laboratorium Ilmu Nutrisi dan Pakan Fakultas Peternakan dan Pertanian UNDIP; ${ }^{2}$ Berdasarkan rumus Balton (Siswohardjono, 1982); ${ }^{3}$ Berdasarkan Tabel NRC (2004)

Pengambilan darah dilakukan pada umur 3, 6, 9 hari dan pengamatan bobot kuning telur pada umur 2, 3, 4, 5, dan 6 hari masing-masing diambil sampel 5 ekor ayam. Ayam ditimbang kemudian dipotong pada bagian vena jugularis leher kemudian darah ditampung kedalam tabung yang sudah berisi EDTA. Darah dianalisis kadar leukosit serta leukosit diferensial. Ayam yang dipotong kemudian dilakukan nekropsi sehingga sisa kuning telur dapat dipisahkan kemudian ditimbang untuk mengetahui bobot relatif.

\section{HASIL DAN PEMBAHASAN}

\section{Bobot relatif kuning telur}

Bobot relatif kuning telur pada saat anak ayam umur 2 hari adalah paling tinggi bila dibandingkan dengan umur 3,4 , 5 dan 6 hari, sedangkan pada umur 3 hari tidak berbeda nyata dengan umur 4 hari namun berbeda dengan umur 5 dan 6 hari. Bobot relatif kuning telur umur 4 hari tidak berbeda dengan umur 5 hari namun berbeda dengan umur 6 hari, sedangkan umur 5 hari tidak berbeda dengan umur 4 dan 6 hari.

Bobot relatif kuning telur semakin mengecil atau menghilang seiring dengan bertambahnya umur ayam sampai hari ke 6 pasca tetas. Ini dapat dilihat bahwa pada umur 2 hari bobot relatif kuning telur lebih besar dan semakin menyusut hingga saat umur 6 hari. Kuning telur nampak sangat kecil pada hari ke 6, karena ayam sudah membutuhkan asupan ransum dari luar. Abbas (2009) menyatakan bahwa anak ayam setelah menetas masih memiliki sisa kuning telur dalam waktu 5 hari setelah menetas.

Bobot relatif kuning telur menunjukkan bahwa tidak ada interaksi yang nyata $(\mathrm{P}>0,05)$ antara umur ayam Kedu pasca tetas dan pemberian ransum berbeda. Hasil sidik ragam menunjukkan bahwa umur ayam berpengaruh nyata $(\mathrm{P}<0,05)$ terhadap bobot relatif kuning 
telur, sedangkan pemberian ransum berbeda tidak berpengaruh nyata (Tabel 2).

Tabel 2. Rerata bobot relatif kuning telur sampai umur 6 hari pada Ayam Kedu pasca tetas yang dipuasakan dan diberi ransum berbeda kualitas nutrisi

\begin{tabular}{|c|c|c|c|c|c|}
\hline Umur & T0 & $\mathrm{T} 1$ & $\mathrm{~T} 2$ & Rerata & Penyusutan \\
\hline (Hari) & ------ & "----------- & -------\%------ & ------------ & --------- \\
\hline 2 & 9,17 & 6,34 & 8,07 & $7,86^{\mathrm{a}}$ & - \\
\hline 3 & 5,26 & 5,58 & 2,65 & $4,49^{b}$ & 3,37 \\
\hline 4 & 2,94 & 2,44 & 3,23 & $2,87^{\mathrm{bc}}$ & 1,62 \\
\hline 5 & 2,04 & 1,48 & 1,42 & $1,65^{\mathrm{cd}}$ & 1,22 \\
\hline 6 & 0,39 & 0,79 & 0,73 & $0,64^{d}$ & 1,01 \\
\hline Rerata & 3,96 & 3,29 & 3,22 & 3,50 & \\
\hline Penyusutan & $\begin{array}{c}0,67 \\
\text { (T0 vs T1) }\end{array}$ & $\begin{array}{c}0,74 \\
\text { (T0 vs T2) }\end{array}$ & $\begin{array}{c}0,07 \\
\text { (T1 vs T2) }\end{array}$ & & \\
\hline
\end{tabular}

Sisa kuning telur yang tersimpan dalam tubuh anak ayam pasca tetas berfungsi sebagai cadangan nutrisi dan sebagai sumber nutrisi untuk daya tahan tubuh. Kuning telur memberikan nutrisi untuk embrio yang berkembang pada saat proses penetasan, dan kuning telur yang tersisa pada akhir inkubasi berfungsi sebagai sumber nutrisi selama beberapa hari pasca penetasan (Kear, 1965).

Cadangan kuning telur lebih besar pada anak ayam yang dihasilkan atau ditetaskan dari telur yang berukuran lebih besar dan tentunya akan lebih membantu kelangsungan hidup dan aktivitas ayam dalam suplai nutrien untuk mempertahankan hidup (Parsons, 1970) selama tidak terdapat kematian anak ayam pada semua ulangan. Faktor ransum berbeda kualitas tidak berpengaruh terhadap bobot relatif kuning telur, namun bila dilihat nilai rerata pada tiap perlakuan nampak adanya penurunan terutama antara perlakuan T0 (dipuasakan 3 hari pasca tetas) dengan yang tidak dipuasakan atau diberi ransum peternak (T1) dan perbaikan (T2).

Bobot relatif kuning telur paling tinggi ditemukan pada kelompok ayam yang dipuasakan 3 hari pasca tetas. Hal ini menunjukkan bahwa penyusutan kuning telurnya lebih lambat karena sisa kuning telur yang tersimpan dalam tubuh ayam pasca tetas sampai umur 6 hari digunakan untuk sumber nutrisi guna bertahan hidup karena ayam tidak mendapatkan sumber energi atau nutrisi dari luar ransum.

Kuning telur pada anak ayam yang diberi ransum baik formula peternak (T1) maupun perbaikan (T2) lebih cepat menyusut karena selain digunakan untuk cadangan nutrisi, kuning telur juga digunakan untuk membantu merangsang kerja saluran pencernaan terutama pada usus. Berbeda dengan ayam yang dipuasakan, kuning telur hanya digunakan sebagai cadangan makanan untuk mempertahankan hidup dan tidak digunakan untuk kerja saluran pencernaan karena belum ada makanan yang masuk kedalam saluran pencernaan. Noy dan Sklan (1999) menyatakan bahwa kuning telur dalam tubuh anak ayam selain berperan sebagai cadangan nutrien, sisa kuning telur juga dapat merangsang perkembangan sistem pencernaan dan fungsi penyerapan usus sebagai persiapan usus pada saat umur selanjutnya.

\section{Profil leukosit dan leukosit diferensial}

Pemberian ransum berbeda kualitas dan umur tidak menunjukkan adanya interaksi terhadap profil leukosit dan leukosit diferensial pada ayam Kedu sampai 6 hari pasca tetas. Faktor umur ayam maupun pemberian ransum dengan kualitas berbeda tidak berpengaruh nyata $(\mathrm{P}>0,05)$ terhadap profil leukosit dan 
leukosit diferensial pada ayam kedu pasca

tetas (Tabel 3).

Tabel 3. Rerata profil leukosit dan leukosit diferensial pada anak Ayam Kedu yang dipuasakan dan diberi ransum berbeda kualitas nutrisinya

\begin{tabular}{|c|c|c|c|c|c|}
\hline Parameter & Umur & T0 & $\mathrm{T} 1$ & $\mathrm{~T} 2$ & Rerata \\
\hline \multirow{5}{*}{ Leukosit } & (Hari) & --------. & --------. & -------. & ------- \\
\hline & 3 & 9350,0 & 8500,0 & 8120,0 & 8656,7 \\
\hline & 6 & 8690,0 & 8440,0 & 7820,0 & 8316,7 \\
\hline & 9 & 8210,0 & 7470,0 & 7370,0 & 7683,0 \\
\hline & Rerata & 8746,7 & 8136,7 & 7770,0 & \\
\hline \multirow{4}{*}{ Heterofil } & 3 & 4456,3 & 3813,8 & 3769,6 & 4013,2 \\
\hline & 6 & 3786,7 & 3551,4 & 3406,6 & 3581,6 \\
\hline & 9 & 3469,7 & 3278,1 & 2818,0 & 3188,6 \\
\hline & Rerata & 3904,2 & 3547,8 & 3331,4 & \\
\hline \multirow{4}{*}{ Limfosit } & 3 & 4332,8 & 4011,8 & 3787,4 & 4044,0 \\
\hline & 6 & 2712,0 & 4118,0 & 4100,2 & 4342,7 \\
\hline & 9 & 4359,1 & 3685,5 & 4091,4 & 4045,2 \\
\hline & Rerata & 4386,2 & 4052,7 & 3993,0 & \\
\hline
\end{tabular}

Hasil rerata leukosit untuk faktor pemberian ransum maupun umur ayam menunjukkan angka antara 7000-9000 $\mathrm{jt} / \mu \mathrm{l}$. Hasil tersebut masih dalam kisaran normal walaupun secara numerik terjadi penurunan yang tidak signifikan. Ini artinya anak ayam Kedu 6 hari pasca tetas berada dalam keadaan sehat dan mempunyai daya tahan tubuh yang baik meskipun dipuasakan atau diberi ransum peternak (T1) ataupun perbaikan (T2). Penelitian Zinkl (1986) yang disitasi oleh Hamzah dkk. (2012) menyatakan bahwa kisaran normal jumlah leukosit unggas pada umur 21 hari yaitu 12.000-30.000 per $\mathrm{mm}^{3}$. Menurut Regar dkk. (2014), leukosit pada ayam broiler umur 3 minggu yang sehat sebanyak $8700 \mathrm{sel} / \mathrm{mm}^{3}$ dan lebih rendah apabila dibandingkan dengan yang sakit yaitu sebesar $17500 \mathrm{sel} / \mathrm{mm}^{3}$ pada umur yang sama. Peningkatan jumlah ini dikarenakan adanya respon tubuh terhadap benda asing atau bibit penyakit yang masuk kedalam tubuh ayam. Tubuh ayam kemudian merespon dengan meningkatkan produksi sel leukosit untuk dilepaskan kedalam darah.

Perlakuan kontrol T0 (dipuasakan) menghasilkan nilai rerata leukosit cenderung tinggi, sedangkan perlakuan T2 cenderung rendah. Ini menunjukkan bahwa semakin baik ransum yang diberikan semakin rendah jumlah leukosit. Hal ini dimungkinkan ada keterkaitan dengan cadangan kuning telur yang juga tinggi pada kelompok ayam yang dipuasakan (T0). Kandungan nutrisi dalam kuning telur dengan tanpa bantuan asupan nutrien dari ransum tetap mampu menjaga stabilitas jumlah leukosit bahkan lebih tinggi dari pada yang diberi asupan nutrisi dari luar. Widjaja (1999) menyatakan bahwa sisa kuning telur dalam tubuh anak ayam tersusun dari $50 \%$ air, $28 \%$ protein, 20\% lemak, dan 7\% maternal antibodi. Protein merupakan nutrisi dalam ransum yang dapat membantu dalam pembentukan antibodi dalam tubuh. Tizzard (1982) menyatakan bahwa protein merupakan molekul yang terdapat dalam ransum yang digunakan untuk pembentukan antibodi dalam tubuh unggas. Selain kandungan protein yang tinggi, cadangan kuning telur juga mengandung vitamin A dan E yang mampu meningkatkan daya tahan tubuh anak ayam Kedu. Berdasarkan data Kementerian Kesehatan Republik Indonesia bahwa dalam 100 g kuning telur terdapat 2000 IU vitamin A. Setiap DOC pasca tetas memiliki cadangan makanan berupa sisa kuning telur yang mengandung Vitamin A dan vitamin E yang berguna 
sebagai antioksidan untuk membantu daya tahan hidup DOC (Pattison, 1993).

Leukosit anak ayam pasca tetas yang diberi ransum perbaikan (T2) menghasilkan bobot badan yang baik, meskipun jumlah leukosit ada pada batas paling rendah dalam kisaran normal. Bobot badan ayam pada T2 (36,53 g) lebih tinggi bila dibandingkan dengan T0 (30,63 g). Bobot badan yang baik menunjukkan bahwa ayam sehat dan daya tahan tubuh baik yang ditunjukkan pula dengan jumlah leukosit yang menurun. Menurut Addas et al. (2012) yang disitasi oleh Etim et al., (2014) bahwa faktor yang mempengaruhi jumlah leukosit antara lain kondisi lingkungan, umur dan kandungan nutrisi ransum.

Semakin bertambah umur ayam (3 sampai 9 hari), jumlah leukosit semakin rendah atau menurun meskipun secara statistik tidak nyata berbeda. Bertambahnya umur ayam maka pertumbuhan juga semakin baik ini menandakan ayam sehat dan ayam tidak sedang terserang penyakit yang ditunjukkan jumlah leukosit yang rendah. Menurut Guyton dan Hall (1997), perubahan profil darah dapat disebabkan faktor internal seperti pertambahan umur ayam. Lingkungan sekitar kandang tempat pemeliharaan tidak dapat dikendalikan dari adanya bibit penyakit, maka kondisi leukosit yang rendah namun bobot badan yang baik membuktikan bahwa ayan Kedu pasca tetas mampu beradaptasi dan tetap tumbuh dengan baik.

Hasil rerata heterofil pada ayam Kedu 6 hari pasca tetas menunjukkan angka 2818-4456 jt/ $\mu \mathrm{l}$ dan limfosit 2712$4456 \mathrm{jt} / \mu \mathrm{l}$. Hasil tersebut masih dalam kisaran normal walaupun secara numerik terjadi penurunan yang tidak signifikan. Ini artinya anak ayam Kedu masih dalam kondisi sehat meskipun ada yang dipuasakan 3 hari pasca tetas dan ada yang diberi ransum peternak (T1) dan perbaikan (T2). Penelitian Ismoyowati dkk. (2012) pada pengamatan jumlah limfosit dan heterofil pada itik umur 21 hari masing- masing berkisar antara 1518-2095 sel/ $\mu \mathrm{l}$ dan 2169-6354 sel/ $\mu \mathrm{l}$.

Kelompok ayam yang dipuasakan (T0) memberikan rerata heterofil dan limfosit sedikit lebih tinggi dibandingkan dengan kelompok ayam yang diberi ransum formula peternak (T1) dan perbaikan (T2). Ini memberikan arti bahwa pemberian ransum baik formula peternak maupun perbaikan memberikan respon yang lebih baik terhadap ketahanan tubuh yang ditunjukkan dengan jumlah heterofil dan limfosit yang sedikit menurun meskipun tidak nyata, sehingga nutrien ransum dikonsentrasikan untuk pertumbuhan. Hal ini selaras dengan data bobot badan seperti yang telah dijelaskan sebelumnya. Menurut Puvadolpirod dan Thaxton (2000), salah satu faktor yang mempengaruhi tinggi rendahnya heterofil antara lain kecukupan nutrisi ransum, terutama protein.

\section{KESIMPULAN}

Bobot relatif kuning telur dan profil leukosit maupun leukosit diferensial pada ayam Kedu pasca tetas tetap stabil meskipun diberi ransum dengan kualitas nutrien berbeda ataupun ayam yang dipuasakan tiga hari pasca tetas.

\section{DAFTAR PUSTAKA}

Abbas, M. H. 2009. Fisiologi pertumbuhan ternak. Andalas University Press. Padang.

Addass, P. A., David, I. Edward, A. Zira dan Midak. 2012. Effect of age, sex and management system on some haematological parameters of intensively and semi-intensively kept chicken in Mubi. Adamawa State, Nigeria. Iranian J. of App. Anim. Sci. 2 (3) : 277 - 282 dalam Etim, N., E. Enyinihi, U. Akpabio dan Edem. 2014. Effects of nutrition on haemotology of rabbits : A review. J. European Sci. 10 (3): $413-423$.

Arvah, N. M. 2015. Pengaruh pemberian tepung kunyit pada ransum 
terhadap jumlah eritrosit, hemoglobin, PCV, dan leukosit ayam broiler. Universitas Hasanuddin.

Gonzales, E. N. S. M. Leander., J. C. Varoli Ju 'Danior., T. S. Takita., and M. M. Loddi. 2000. Or do newborn jejum tempo restrictions, a precocious power of Frangos influencing cutting produtividade Idade na trophy. Brazl J. Sci Avicola. Suppl. 2: 4.

Guyton, A. C, dan J. E. Hall. 1997. Fisiologi kedokteran. Buku Ajar. Alih Bahasa Setiawan, I., K. A. Tengadi, A. Santoso. Penerbitan Buku Kedokteran EGC. Jakarta.

Ismoyowati, M., Samsi., dan M. Mufti. 2012. Different haemotological condition, immune system and comfortof muscofu duck and lokan duck reared in dry and wet seasons. Universitas Jendral Soedirman. Purwokerto.

Kear, J. 1965. The internal food reserves of hatching mallard ducklings. J. Wild Manag. 29: 523 - 528.

Mayes, P. A., R. K. Murray, D. K. Granner, and V. W Rodwell. 1997. Biokimia harper. 24th Ed. Buku Kedokteran, Jakarta.

Nataamijaya, A. G. 2008. Karakteristik dan produktivitas ayam Kedu hitam. Bul. Plasma Nutfah 14 (2): 85 - 89.

Noy, Y. and D. Sklan. 1999. Energy utilization in newly hatched chicks. Poult. Sci. 78:1750-1756.

Parsons, J. 1970. Relationship between egg size and post-hatching chick mortality in the Herring Gull (Larus argentatus). Nature 228: 1221 - 1222.

Pattison, M. 1993. The health of poultry. Longman scientific and technical. Philadelphia.

Puvadolpirod, S and Thaxton, J. P. 2000a. Model of physiological stress in chickens. Poult Sci. 79: 363- 369.
Redmond, S. B., P. Chuammitri., C. B. Andreasen., D. Palic., S. J. Lamont. 2011. Genetic control of chicken heterophil function in advanced intercross lines: associations with novel and with known Salmonella resistance loci and a likely mechanism for cell death in extracellular trap production. Immunogenetics. 63: 449 - 458.

Regar, M. N., R. Mutia, S. D. Widhyari, dan Y. H. S. Kowel. 2014. Pengaruh pemberian ransum kombinasi suplemen herbal dengan mineral zink terhadap jumlah leukosit, eritrosit, dan kadar hemoglobin broiler yang diinfeksi escherichia coli. J. Zootek. 34. (2): $82-88$.

Siswohardjono, W. 1982. Beberapa metode pengukuran energi metabolis bahan makanan ternak pada itik. Institut Pertanian Bogor. Bogor.

Tizard, I. R. 1982. Pengantar Imunologi Veteriner. Edisi ke-2. Penerjemah: M Partodiredjo. Airlangga University Press. Surabaya.

Widjaja, H. 1999. Bolehkah ayam dipuasakan. Poultry Indonesia. 233 : $33-34$.

Yalcinkaya, L., T. M. Gonggor., Basalan and E. Erdem. 2008. Mannan oligosaccharides (MOS) from Saccharomyces cerevisiae in broilers: Effects on performance and blood biochemistry. Turk. J. Vet. Anim. Sci. 32 (1) : $43-48$.

Zinkl J G. 1986. Avian hematology. Veterinary Hematology. 4th Ed. Philadelphia. Lea and Febiger dalam Hamzah, R. A., I. Wiryanti., D. A. Astuti, F. Satrija. 2012. Tanggap kebal dan tampilan produksi ayam pedaging yang diberi ekstrak buah mengkudu. J. Vet. 13. (1) : 34 - 42. 